\title{
Prevalence of osteoporosis, serum vitamin D and serum calcium deficiency cases among women: A hospital based retrospective study
}

\author{
Shadab S Rangrez ${ }^{1}$, Chetana. P. Hadimani ${ }^{2, *}$, Ashwin. S. Patil ${ }^{3}$ \\ ${ }^{1}$ Post Graduate Student, ${ }^{2}$ Associate Professor, ${ }^{3}$ Professor, ${ }^{1,2}$ Dept. Biochemistry, ${ }^{3}$ Dept. of Radiology, KAHER (Deemed-to-be- \\ University), Jawaharlal Nehru Medical College, Belagavi, Karnataka, India
}

*Corresponding Author: Chetana. P. Hadimani

Email: chetanaph@gmail.com

Received: $12^{\text {th }}$ July, 2018

Accepted: $17^{\text {th }}$ July, 2018

\begin{abstract}
Introduction: Osteoporosis is a disorder of the bones characterized by low bone mass.One out of three women in India suffers from osteoporosis. Vitamin D deficiency prevails as an epidemic in India and a formidable issue. The present study was done to estimate prevalence of osteoporosis rates among women and correlation of BMD with serum vitamin D and calcium levels.

Materials and Methods: The present retrospective study was conducted on 162 women who attended orthopedic OPD at KLE's hospital, Belagavi.Cases were evaluated for serum $25(\mathrm{OH})$ vitamin D, serum calcium and bone mineral density by DEXA (Lumbar spine) scan.Data analyzed by SPSS version 20.

Results: Results of our study showed $54.3 \%$ of women were osteoporotic, $26.5 \%$ were osteopenic and $19.1 \%$ were having a normal BMD. The highest hypovitaminosis $\mathrm{D}$ was seen in 60 above age group. There was a significant and positive correlation between BMD scores with vitamin $\mathrm{D}(\mathrm{r}=0.6644, \mathrm{p}=0.0001)$ and calcium $(\mathrm{r}=0.5974, \mathrm{p}=0.0001)$ at $5 \%$ level was observed. A statistically significant association was found between age group and BMD (chi-square $=14.9597, \mathrm{p}=0.0004$ ), and serum vitamin $\mathrm{D}$ status in women (chi-square $=11.8052, \mathrm{p}=0.0189$ ). Further, multiple linear regression analysis indicated, the influence of vitamin $\mathrm{D}$ and calcium on BMD is positive and significant $(t=35.2502, \mathrm{p}=0.0001)$.

Conclusion: Serum vitamin D and calcium were the significant predictors of BMD in women. It was compelling to observe age was an important factor for high prevalence of low BMD.Hence, prevention and early detection of hypovitaminosis D and hypocalcemia is the key to reduce the incidence of osteoporosis among women.
\end{abstract}

Keywords: Bone mineral density, Osteoporosis, 25 hydroxy vitamin D, Hypocalcemia, DEXA scan.

\section{Introduction}

Osteoporosis is a specific term referring to a state of reduced mass per unit volume of a mineralized bone because of decreased bone proteins. ${ }^{1}$ According to International Osteoporosis Foundation (IOF), one out of three women in India suffers from osteoporosis. ${ }^{2}$ Low bone density exhibits the main risk factor for osteoporosis, other risk factor includes progressive age, early menopause and reduced intake of calcium and vitamin D along with lack of sunlight exposure. ${ }^{3,4}$ There is an increased prevalence of osteoporosis among postmenopausal women and the elderly. ${ }^{5}$ Nearly 30 percent of all postmenopausal women across globally have osteoporosis. It is estimated that 50 percent of women will be experiencing osteoporotic related fractures. ${ }^{6}$

According to our knowledge few studies were done on prevalence of osteoporosis in this part of southern India. Reports of studies from Andhra Pradesh, Tamil Nadu concluded that low dietary calcium intake and lack of limited exposure to sunlight are associated with low bone mineral density. ${ }^{7,8}$ Hence the present hospital based study was done to estimate the osteoporotic, serum vitamin $\mathrm{D}$ and calcium deficiency cases among women of different age groups and correlation of BMD with serum vitamin D and calcium levels.

\section{Materials and Methods}

The present retrospective study was conducted on women, who visited orthopedic OPD under executive health check-up at KLE Society's Dr. Prabhakar Kore Charitable Hospital, Belagavi, India, between 2014 and 2016. The total numbers of 252 cases were evaluated and after fulfilling the selection criteria, 162 women case reports were taken up for the study. Cases with renal disease, malnutrition, thyroid, parathyroid diseases, history of cancer, estrogen replacement therapy or therapy with any other drug that affect skeleton like steroids, anti-Convulsants and anticoagulants were excluded. Further, based on age women were grouped into three categories as 20-40 years $(n=24), 41-59$ years $(n=49)$ and $>60$ years $(n=89)$. The parameters for serum $25(\mathrm{OH})$ vitamin D, serum calcium and DEXA (Lumbar spine) scan reports were collected from the medical record department.The study was approved by the institutional ethical and research committee.

The serum $25(\mathrm{OH})$ vitamin D and calcium samples were estimated by chemiluminescent immunoassay and Bis (o-Aminophenoxy)ethane-tetra-acetic acid)BAPTA method respectively on Roche/Hitachi cobas c analyser. As per latest recommendation on serum $25(\mathrm{OH})$ vitamin D levels subjects were grouped as vitamin $\mathrm{D}$ deficient with $\leq 20 \mathrm{ng} / \mathrm{ml}$, insufficient with $21-29 \mathrm{ng} / \mathrm{ml}$ and sufficient with $>30 \mathrm{ng} / \mathrm{ml} .^{9,10}$ Bone mineral density $\left(\mathrm{g} / \mathrm{cm}^{2}\right)$ measurement was estimated 
using DEXA scan of GE Wipro and Lunar densitometer at lumbar spine (L1-L4 level). Subjects were divided as normal T-scores of -1 or above, osteopenia with $\mathrm{T}$ - score between -1.0 and -2.5 and osteoporosis with T-score of 2.5 or lower. ${ }^{2,11}$

Statistical analysis was performed using the SPSS Software, version 20.0 for windows. Continuous variables were expressed as mean, median \pm S.D and qualitative data were expressed in percentages. ChiSquare test was used to associate the parameters with age groups. The correlation between continuous variables was done by Karl Pearson's coefficient correlation method. p-value $<0.05$ was considered as significant.

\section{Results}

In the present study, out of 162 women, $14.8 \%$ were in $20-40$ age groups, $30.2 \%$ were in $41-59$ age groups and $55 \%$ were in 60 above age group. Mean values for $\operatorname{BMD}\left(\mathrm{g} / \mathrm{cm}^{2}\right)$ was $0.91+0.21,25(\mathrm{OH})$ vitamin $\mathrm{D}(\mathrm{ng} / \mathrm{ml})$ was $15.23 \pm 11.73$ and Calcium $(\mathrm{mg} / \mathrm{dl})$ was $8.36 \pm 2.53$. However, maximum patients were osteoporotic $(54.3 \%)$ compared to osteopenia $(26.5 \%)$ and normal $(19.1 \%)$. The association between age group and BMD status was found to be statistically significant (chi-square $=14.9597$, $\mathrm{p}=0.0004$ ) as shown in Table. 1
A statistically significant association was found between age group and serum vitamin D status in women (chi-square $=11.8052, \mathrm{p}=0.0189$ ). Maximum patients were vitamin D deficient $(73.4 \%)$ compared to insufficient $(10.5 \%)$ and normal $(16 \%)$ cases. Among deficient cases $(n=119)$, the highest number of patients belonged to 60 above age group $(n=74)$ as shown in Table 2 .

Table 3 shows the association of age groups with serum calcium level among women. Calcium deficiency cases were maximum $(67.2 \%)$ compared with hypercalcaemia $(8.1 \%)$ and normal $(20.3 \%)$. However, the association between age groups and serum calcium was found to be statistically significant (chisquare $=11.069, \mathrm{p}=0.0258$ ).

Table 4 shows a significant and positive correlation between BMD with $25(\mathrm{OH})$ vitamin $\mathrm{D}(\mathrm{r}=0.6644$, $\mathrm{p}=0.0001)$ and BMD with calcium $(\mathrm{r}=0.5947, \mathrm{p}=0.0001)$ at $5 \%$ level was observed. It means that the BMD, serum $25(\mathrm{OH})$ vitamin $\mathrm{D}$ and serum calcium are dependent on each other. Further, multiple linear regression analysis indicated that serum $25(\mathrm{OH})$ vitamin $\mathrm{D}$ and serum calcium were the significant predictors of BMD in women. It means that the influence of $25(\mathrm{OH})$ vitamin $\mathrm{D}$ and calcium on BMD is positive and significant $(\mathrm{t}=35.2502, \mathrm{p}=0.0001)$ as shown in Table 5 .

Table 1: Association between Age group and BMD in women

\begin{tabular}{|c|c|c|c|c|c|c|c|c|c|c|}
\hline \multirow{2}{*}{$\begin{array}{c}\text { Age group } \\
(\mathrm{n}=162)\end{array}$} & \multirow{2}{*}{$\begin{array}{c}\text { Normal } \\
\text { (T-score of - } \\
1 \text { or above) }\end{array}$} & \multirow[t]{2}{*}{$\%$} & \multirow{2}{*}{$\begin{array}{c}\text { Osteopenia } \\
\text { (T- score } \\
-1.0 \text { to- } 2.5)\end{array}$} & \multirow[t]{2}{*}{$\%$} & \multirow{2}{*}{$\begin{array}{c}\text { Osteoporosis } \\
\text { (T-score }-2.5 \\
\text { or lower) }\end{array}$} & \multirow[t]{2}{*}{$\%$} & \multicolumn{2}{|c|}{ Total } & \multirow{2}{*}{$\begin{array}{c}\text { Chi- } \\
\text { square }\end{array}$} & \multirow[t]{2}{*}{ p-value } \\
\hline & & & & & & & $\mathbf{n}$ & $\%$ & & \\
\hline $20-40$ & 6 & 25 & 10 & 41.6 & 8 & 33.3 & 24 & 14.8 & 14.9597 & $0.0004^{*}$ \\
\hline $41-59$ & 14 & 28.5 & 15 & 30.6 & 20 & 40.8 & 49 & 30.2 & & \\
\hline $60>$ & 11 & 12.3 & 18 & 20.2 & 60 & 67.4 & 89 & 55 & & \\
\hline Total & 31 & 19.1 & 43 & 26.5 & 88 & 54.3 & 162 & 100 & & \\
\hline
\end{tabular}

$* \mathrm{p}<0.05$

Table 2: Association between age group and serum vitamin $D$ in women

\begin{tabular}{|c|c|c|c|c|c|c|c|c|c|c|}
\hline \multirow{2}{*}{$\begin{array}{c}\text { Age } \\
\text { group } \\
(\mathrm{n}=162)\end{array}$} & \multirow{2}{*}{$\begin{array}{c}\text { Deficient } \\
(\leq 20 \mathrm{ng} / \mathrm{ml})\end{array}$} & \multirow[t]{2}{*}{$\%$} & \multirow{2}{*}{$\begin{array}{c}\text { Insufficient } \\
(21-29 \\
\mathrm{ng} / \mathrm{ml})\end{array}$} & \multirow[t]{2}{*}{$\%$} & \multirow{2}{*}{$\begin{array}{c}\text { Sufficient } \\
(\geq 30 \mathrm{ng} / \mathrm{ml})\end{array}$} & \multirow[t]{2}{*}{$\%$} & \multicolumn{2}{|c|}{ Total } & \multirow{2}{*}{$\begin{array}{c}\text { Chi- } \\
\text { square }\end{array}$} & \multirow[t]{2}{*}{ p-value } \\
\hline & & & & & & & $\mathbf{n}$ & $\%$ & & \\
\hline $20-40$ & 16 & 66.6 & 4 & 16.6 & 4 & 16.6 & 24 & 14.8 & 11.8052 & 0.0189 * \\
\hline $41-59$ & 29 & 59.1 & 6 & 12.2 & 14 & 28.5 & 49 & 30.2 & & \\
\hline $60>$ & 74 & 83.1 & 7 & 7.8 & 8 & 8.9 & 89 & 54.9 & & \\
\hline Total & 119 & 73.4 & 17 & 10.5 & 26 & 16 & 162 & 100 & & \\
\hline
\end{tabular}

$* \mathrm{p}<0.05$

Table 3: Association between Age group and serum calcium in women

\begin{tabular}{|c|c|c|c|c|c|c|c|c|c|c|}
\hline \multirow{2}{*}{$\begin{array}{c}\text { Age group } \\
(\mathrm{n}=162)\end{array}$} & \multirow{2}{*}{$\begin{array}{c}\text { Normal } \\
(8-11 \\
\text { mg/dl })\end{array}$} & \multirow[t]{2}{*}{$\%$} & \multirow{2}{*}{$\begin{array}{l}\text { Hypocalcemia } \\
\text { ( } \leq 8 \mathrm{mg} / \mathrm{dl})\end{array}$} & \multirow[t]{2}{*}{$\%$} & \multirow{2}{*}{$\begin{array}{l}\text { Hypercalcemia } \\
\text { ( } \geq 11 \mathrm{mg} / \mathrm{dl})\end{array}$} & \multirow[t]{2}{*}{$\%$} & \multicolumn{2}{|c|}{ Total } & \multirow{2}{*}{$\begin{array}{l}\text { Chi- } \\
\text { square }\end{array}$} & \multirow[t]{2}{*}{ p-value } \\
\hline & & & & & & & $\mathbf{n}$ & $\%$ & & \\
\hline $20-40$ & 4 & 17.3 & 16 & 66.6 & 4 & 17.3 & 24 & 14.8 & 11.069 & $0.0258^{*}$ \\
\hline $41-59$ & 17 & 34.6 & 25 & 51.0 & 7 & 14.2 & 49 & 30.2 & & \\
\hline $60>$ & 12 & 13.4 & 68 & 76.4 & 9 & 10.1 & 89 & 54.9 & & \\
\hline Total & 33 & 20.3 & 109 & 67.2 & 20 & 8.1 & 162 & 100 & & \\
\hline
\end{tabular}

$* \mathrm{p}<0.05$ 
Table 4: Correlation between BMD with serum vitamin D and serum calcium in women by Karl Pearson's correlation coefficient method

\begin{tabular}{|l|c|c|c|}
\hline \multirow{2}{*}{ Independent variables } & \multicolumn{3}{|c|}{ Correlation between BMD with } \\
\cline { 2 - 4 } & r-value & t-value & p-value \\
\hline $25(\mathrm{OH})$ Vitamin D $(\mathrm{ng} / \mathrm{ml})$ & 0.6644 & 10.4833 & $0.0001^{*}$ \\
\hline Calcium $(\mathrm{mg} / \mathrm{dl})$ & 0.5947 & 8.3562 & $0.0001^{*}$ \\
\hline * $<0.05$ &
\end{tabular}

Table 5: Multiple linear regression analysis of BMD by serum 25(OH) vitamin D and serum calcium in women

\begin{tabular}{|l|c|c|c|c|}
\hline Independent variable & Co-efficient & SE of co-effcient & t-value & p-value \\
\hline Intercept & 0.7241 & 0.0205 & 35.2502 & $0.0001^{*}$ \\
\hline $\begin{array}{l}25(\mathrm{OH}) \text { Vitamin D } \\
(\mathrm{ng} / \mathrm{ml})\end{array}$ & 0.0120 & 0.0011 & 11.2448 & $0.0001^{*}$ \\
\hline Calcium & 0.0305 & 0.0212 & 8.7895 & 0.0001 \\
\hline
\end{tabular}

$* \mathrm{p}<0.05$

\section{Discussion}

Osteoporosis is the general metabolic bone disease in clinical practice, its prevalence is incremental with the rise in ageing population and it is vital health problem worldwide. $^{12}$

In this hospital based retrospective study out of 162 women, maximum patients were osteoporotic $(54.3 \%)$ compared to osteopenia (26.5\%) and normal (19.1\%). Similar study in Vellore, reported $48 \%$ prevalence of osteoporosis among women. ${ }^{4}$ In our study there was significant association found between age groups and lumbar spine- BMD. This indicated that as the age increases, there is a decrease in BMD status. In comparative studies, they concluded that age correlated with lower BMD values. ${ }^{13,14}$

The study showed the highest percentage of vitamin D deficiency were observed among women of more than 60 years age group. All the deficient individuals were osteoporotic or osteopenic. A similar observation was reported by Harinarayan et al., the highest hypovitaminosis $\mathrm{D}$ were seen in 60 above age group and $83.1 \%$ women were vitamin D deficient. ${ }^{7}$ In contrary to our study, A.P.S Narang concluded that there was no significance with age and vitamin D levels. ${ }^{15}$

The correlation between serum calcium and serum $25(\mathrm{OH})$ vitamin $\mathrm{D}$ was found out to be significant and the parameters were dependent on each other along with BMD. There was a positive correlation between BMD at lumbar spine and serum $25(\mathrm{OH})$ vitamin D status. It was evident that $25(\mathrm{OH})$ vitamin D status influenced BMD positively. Similar findings were reported by many studies. ${ }^{16-20}$

\section{Conclusion}

In conclusion, the present study demonstrates the prevalence of osteoporosis, vitamin D deficiency and hypocalcemia cases were reported maximum among women. It was compelling to observe age was an important factor for high prevalence of low BMD and vitamin D deficiency. Serum $25(\mathrm{OH})$ vitamin D and serum Calcium were the significant predictors of BMD. The routine use of biochemical parameters like serum $25(\mathrm{OH})$ vitamin $\mathrm{D}$, serum calcium and DEXA scan would aid in the early diagnosis and prevention of osteoporosis and its related fractures. These findings would help health professionals to create awareness about vitamin D deficiency among women.

\section{References}

1. Ednezar J. Textbook of orthopaedic: geriatric orthopaedic. $4^{\text {th }}$ edition. New Delhi: Jaypee publication; 2010;668-69.

2. Assessment of fracture risk and its application to screening for postmenopausal osteoporosis. Report of a WHO study Group, Geneva, World Health Organisation, 1994 (WHO technical Report series, No.

843).http://www.who.int/iris/handle/10665/39142.

3. Weinstein L S and Buckwater A J. Turek's orthopaedics Principles and their applications: Metabolic bone disease. Osteoporosis: Scope and problem. $6^{\text {th }}$ edition. Philadelphia: Lippincott Williams \& Wilkins;2005;202-6.

4. Kadam N, Chiplonkar S, Khadilkar A, Divate U \& Khadilkar V. Low bone mass in urban Indian women above 40 years of age: prevalence $\&$ risk factors Gynecological endocrinology: the official journal of the International Society of Gynecological Endocrinology. 2010; 26(12):919-17.

5. Rapuri PB, Gallagher JC and Haynatzka V. Protein intake: effects on bone mineral density and the rate of bone loss in elderly women. The American journal of clinical nutrition. 2003;77(6):1517-25.

6. Bock $\mathrm{O}$ and Felsenberg D. Bisphosphonates in the management of postmenopausal osteoporosis-optimizing efficacy in clinical practice. Clin Interv Aging. 2008;3(2):279-297.

7. Harinarayan C.V, Ramalakshmi T, Prasad UV \& Sudhakar D. $25(\mathrm{OH})$ Vitamin D status in Andra Pradesh: A population based study. Indian J Med Res. 2008:127(3):211-218.

8. Paul TV, Thomas N, Seshadri MS, Oammen R, Jose A, Mahendri NV. Prevalence of osteoporosis in ambulatory postmenopausal women from a semi urban region in Sothern India. Endocrine practice: official journal of the American College of Endocrinology and the American Association of Clinical Endocrinologists. 2008;14(6):665-71. 
9. Holick MF. Vitamin D status: measurement, interpretation, and clinical application. Endocrine practice: official journal of the American College of Endocrinology and the American Association of Clinical Endocrinologists. 2009;19(2):73-78.

10. Bischoff-Ferrari HA, Giovannucci E, Willett WC, Dietrich T, Dawson-Hughes B. Estimation of optimal serum concentrations of 25-hydroxyvitamin $\mathrm{D}$ for multiple health outcomes. Am J Clin Nutr. 2006;84(1):1828.

11. Kanis JA, McCloskey EV, Johansson $\mathrm{H}$ et al. European guidance for the diagnosis and management of osteoporosis in postmenopausal women. Osteoporos Int. 2013;24(1):23-57.

12. Hernlund $\mathrm{E}$ et al. Osteoporosis in the European Union: medical management, epidemiology and economic burden. Arch Osteoporos. 2013;8:136.

13. Anuburanjan $\mathrm{M}$ et al. Age-related proximal femur bone mineral loss in South Inda in women: a dual energy X-ray absorptiometry study. J Assoc Physicians India. 2001 Apr;49:442-445.

14. Shukla K, Sharma S, Gupta A, Raizada A, Vinayak K. Current scenario of prevalence of vitamin d Deficiency in ostensibly healthy Indian population: A hospital based retrospective study. Indian journal of clinical biochemistry: IJCB. 2016;31(4):452-457.

15. Narang A, Batra S, Sabharwal S, Ahuja S. 1,25Dihydroxycholecalciferol $\left(1,25-(\mathrm{OH})_{2} \mathrm{D}_{3}\right)$ levels in osteoporosis. Indian journal of clinical biochemistry: IJCB. 2004;19(2):111-113.

16. Narula R, Tauseef M, Iraqi A, Agarwal K, Agarwal A, Arya A. Vitamin D deficiency among postmenopausal women with osteoporosis. Journal of Clinical and Diagnostic Research: JCDR. 2013;7(2):336-38.
17. Batra Sameer, Yamin M, Sabharwal Sanjeev. Relationship between vitamin D insufficiency in osteoporosis and blood bone biochemistry. Indian journal of orthopaedics. 2006;40(1):41-45.

18. Harinarayan Chittari V, Ramalakshmi Tirupati, Upadrasta V Prasad, Desineni Sudhakar, Pemmaraju VLN Srinivasarao, Sarma Kadainti VS, Tiruvenkata Ethamakula G Kumar. High prevalence of low dietary calcium, high phytate consumption, and vitamin D deficiency in healthy south Indians. American Journal of Clinical Nutrition. 2007;85(4):1062-1067.

19. Lips P, Duong T, Oleksik A, Black D, Cummings S, Cox D, Nickelson T. A Global study of vitamin D status and parathyroid function in postmenopausal women with osteoporosis: baseline data from the multiple outcomes of raloxifene evaluation clinical trial. The Journal of clinical endocrinology and metabolism. 2001;86(3):1212-1221.

20. Ghannam NN, Hammami MM, Bakheet SM, Khan BA. Bone mineral density of the spine and femur in healthy Saudi women: relation to vitamin D status, pregnancy, and lactation. Calcified tissue international. 1999;65(1):23-28.

How to cite this article: Rangrez S.S, Hadimani C. P, Patil A. S. Prevalence of osteoporosis, serum vitamin D and serum calcium deficiency cases among women: Ahospital based retrospective study. Int J Clin Biochem Res. 2018;5(4):501-504. 